\title{
PENERAPAN METODE 'ALLIMNA UNTUK MENINGKATKAN KUALITAS MEMBACA AL-QUR'AN PADA ANAK USIA DINI DI TAMAN PENDIDIKAN AL-QUR'AN
}

\author{
Aditya Cindy Pratiwi \\ IAIN Jember \\ e-mail: adityacindypratiwi@gmail.com
}

\begin{abstract}
This research aimed to investigate the application of the 'allimna method in improving the quality of reading the Qur'an in the learning of recitation of qalqalah material for children aged 4-7 years at TPQ Misbahul Huda Gayasan-A Jenggawah Jember. This type of research is classroom action research using the design of Kemmis and Robin Mc. Taggart. The results show that the application of the 'Allimna' method to improve the quality of reading the Qur'an in tajwid learning for the qalqalah material of TPQ Misbahul Huda Gayasan-A Jenggawah Jember students was divided into two cycles. In the first cycle, the percentage of students who completed was 60\% (6 students) of the 10 existing students. Then in the second cycle, there was an increase in the percentage of students who completed to $90 \%$ (9 students), and the number of incomplete students was only $10 \%$ (1 students). The 'allimna method is very effective in improving the ability to read the Qur'an in recitation of recitation of qalqalah material for students of TPQ Misbahul Huda Gayasan-A Jenggawah Jember.
\end{abstract}

Keywords: 'allimna method, reading the Qur'an, tajwid

\begin{abstract}
ABSTRAK
Penelitian ini bertujuan untuk mengetahui penerapan metode 'allimna dalam meningkatkan kualitas membaca Al-Qur'an pada pembealajaran tajwid materi qalqalah pada anak usia 4-7 tahun di TPQ Misbahul Huda Gayasan-A Jenggawah Jember. Jenis penelitian ini adalah penelitian tindakan kelas dengan menggunakan desain rancangan Kemmis dan Robin Mc. Taggart. Hasil penelitian menunjukkan bahwa penerapan metode 'Allimna untuk meningkatkan kualitas membaca Al-Qur'an pada pembelajaran tajwid materi qalqalah santri TPQ Misbahul Huda Gayasan-A Jenggawah Jember terbagi menjadi dua siklus. Pada siklus pertama, jumlah persentase santri yang tuntas adalah $60 \%$ (6 santri) dari 10 santri yang ada. Kemudian pada siklus kedua, terdapat peningkatan jumlah persentase santri yang tuntas menjadi 90\% (9 santri), dan jumlah ketidak tuntasan hanya 10\% (1 santri). Metode 'allimna sangat efektif untuk meningkatkan kemampuan membaca al-Qur'an pada pembelajaran tajwid materi qalqalah santri TPQ Misbahul Huda Gayasan-A Jenggawah Jember.
\end{abstract}

Kata Kunci: metode 'allimna, membaca Al-Qur'an, tajwid 


\section{PENDAHULUAN}

Al-Qur'an merupakan kitab Allah yang diturunkan kepada Nabi Muhammad SAW melalui malaikat Jibril. Al-Qur'an merupakan pedoman bagi siapa saja. Al-Qur'an juga merupakan kitab yang mulia karena membacanya saja sudah bernilai pahala. Membaca Al-Qur'an merupakan salah satu ibadah yang paling agung (Fahrisi, 2020: 12). Maulana Zakariyya menyatakan bahwa keutamaan dalam membaca Al-Qur'an juga sangat banyak diantaranya yakni kita akan mendapatkan pahala dari Allah SWT meskipun membacanya tidak lancar dan mengalami kesulitan, dengan membaca Al-Qur'an hati kita juga akan menjadi tentram, yang dimana disaat kita merasakan gelisah dengan membacanya saja sudah membuat hati kita menjadi tenang karena dengan membaca Al-Qur'an kita banyak-banyak mengingat Allah SWT. Selain mendapatkan keutungan di dunia. Menurut para ulama membaca Al-Qur'an juga akan mendapatkan keuntungan di akhirat dimana diantaranya yaitu Al-Qur'an akan memberikan syafaat kelak bagi siapa saja yang istiqomah dalam membacanya. Selain itu dengan membacanya kita akan mendapatkan kedudukan yang tinggi di surga. Disini membaca Al-Qur'an dengan baik dan benar merupakan hal yang sangat penting bagi umat muslim karena jika terdapat kesalahan maka maknanya juga akan berubah (Syarbani, 2012: 83).

Membaca dan memahami Al-Qur'an ini merupakan suatu keharusan bagi kita sebagai umat muslim. Akan tetapi kualitas membaca seseorang disini berbeda-beda. Ada yang kemampuan membacanya kurang akan tetapi memahami isi kandungan Al-Qur'an dengan baik, dan sebaliknya ada juga yang kemampuan membacanya sangat lancar akan tetapi memahami isi kandungannya kurang. Dan akanlebih baik jika kedua-duanya bisa dikuasai, baik membacanya dengan lancar dan benar ataupun memahami makna isi kandungannya. Dalam membaca Al-Qur'an disini kita tidak hanya sekedar membaca melainkan banyak hal-hal yang harus dipelajari agar kualitas membaca Al-Qur'an itu baik dan benar. Dalam membaca Al-Qur'an yang baik dan benar disini ilmu yang harus dipelajari seperti ilmu tajwid yang harus diperhatikan dalam membacanya. Hal ini sebagaimana dinyatakan para ulama bahwa banyak metode-metode dalam tajwid yang harus dipelajari seperti makharijul huruf, hukum nun atau mim mati, dan juga ada qalqalah yang dimana akan menjadi pembahasan kita saat ini. Disini para ulama menyatakan bahwa hukum mempelajari ilmu tajwid ini sangatlah penting dan mengamalkan disaat membacanya itu menjadi sebuah kewajiban bagi setiap muslim (Marzuki et al., 2020: 31).

Menurut para ulama untuk meningkatkan kualitas dalam membaca Al-Qur'an disini kita harus meningkatkan pemahaman ilmu tajwid. Dimana nantinya santri mampu memahami dan mengamalkan dalam membaca Al-Qur'an. Namun berdasarkan yang saya survey disini kita mendapati mayoritas santri masih belum mampu memahami dan menerapkan ilmu tajwid, yang 
dimana salah satunya yakni qalqalah (Aidah, 2020: 40). Hal ini bisa disebabkan karena beberapa faktor diantaranya yaitu metode pengajarannya yang kurang sesuai, kurangnya pemahaman guru dan masih banyak faktor lain lagi karena disini santri bukan hanya dituntut untuk mempelajari saja namun juga memahami dan mengamalkannya dalam membaca Al-Qur'an.

Berdasarkan pengamatan yang dilakukan terdapat beberapa metode dalam membaca AlQur'an, salah satunya yaitu metode alimna. Metode alimna merupakan metode cepat membaca AlQuran karya LP Ma'arif PCNU Jember yang dinilai jauh lebih efektif dan menyenang (https://allimna.wordpress.com). Bukan hanya sekedar cepat membaca al-Qur'an, melainkan metode ini juga mengajarkan bagaimana cara menerapkan ilmu tajwid yang benar dalam membaca al-Qur'an. Adanya lagu dalam metode alimna menjadi ciri khas tersendiri bagi metode ini. Lagunya yang asyik dan cocok untuk semua kalangan menambah kelebihan dari metode ini. Adanya metode alimna dalam proses pembelajaran membaca Al-Qur'an dinilai efektif dan cocok bagi siapa saja yang ingin memulai belajar membaca Al-Qur'an, termasuk bagi anak usia dini yang berkisar usia 4-7 tahun.

Bagus Priyo Sembodo dalam penelitiannya yang berjudul "Upaya Meningkatkan Prestasi Belajar PAI Materi Pokok Hukum Bacaan Qalaqalah dan Ra' Melalui Metode Drill Pada Siswa Kelas VII SMP Ma'arif 5 Ngrupit Ponorogo 2018-2019" menyatakan bahwa penerapan metode drill dapat meningkatkan prestasi belajar PAI materi hukum bacaan Qalqalah dan Ra' (Sembodo, 2017: 72). Penelitian ini berawal dari rendahnya dan banyaknya siswa yang belum memahami mengenai hukum bacaan qalqalah dan ra'. Dengan permasalahan yang sama, Achmad Bahtiar dalam penelitiannnya yang berjudul "Implementasi Model Pembelajaran Kooperatif Tipe Student Team Achievement Division (STAD) dalam Meningkatkan Prestasi Belajar Siswa Pada Mata Pelajaran Pendidikan Agama Islam Materi Hukum Qalqalah, Ra dan Lam di Kelas IX-4 SMP Negeri 1 Patumbak" menyatakan bahwa prestasi siswa dalam belajar materi hukum qalqalah, ra dan lam meningkat setelah melalui proses penggunaan model STAD dalam pembelajaran (Bahtiar, 2018: 225).

Berangkat dari permasalahan yang serupa yaitu rendahnya pemahaman santri mengenai hukum bacaan qalqalah. Peneliti melakukan penelitian dengan menggunakan metode yang berbeda yakni metode 'Allima. Mengingat banyaknya kelebihan yang ada pada metode 'Alimna, tentu saja metode ini dapat digunakan untuk mengatasi kurangnya pemahaman santri dalam memahami dan menerapkan hukum bacaan qalqalah ketika membaca al-Qur'an di TPQ Misbahul Huda Gayasan-A Jenggawah Jember. Oleh karena itu, kami melakukan penelitian tindakan kelas yang berjudul "Penerapan Metode 'Allimna Untuk Meningkatkan Kualitas Membaca Al-Qur'an Pada Anak Usia Dini di Taman Pendidikan Al-Qur'an." Lokus penelitian ini adalah TPQ Misbahul Huda GayasanA Jenggawah Jember. 


\section{METODE PENELITIAN}

Penelitian ini adalah penelitian tindakan kelas. Desain penelitian ini menggunakan rancangan Kemmis dan Robin Mc. Taggart. Rancangan Kemmis dan Taggart mencakup siklus yang tetrdiri dari tahap-tahap perencanaan (planning), tindakan (action), dan pengamatan (observasi) dan refleksi (Pandiangan, 2019: 20). Adapun penjelasannya sebagai berikut:

1. Rencana yaitu rencana tindakan apa yang akan dilakukan untuk memperbaiki, meningkatkan atau perubahan perilaku dan sikap sebagai solusi. Pada tahap perencanaan penliti menyusun dan mempersiapkan instrumen-instrumen penelitian, Rencana Pelaksanaan Pembelajaran (RPP), bahan ajar dan soal test.

2. Tindakan yaitu apa yang dilakukan guru atau peneliti berdasarkan apa yang telah direncanakan pada tahap perencanaan sebelumnya. Peneliti melakukan dua tidakan dalam penelitian ini yaitu pra tindakan dan tindakan. Yang mana pra tindakan digunakan untuk melihat sebagaimana santri paham mengenai materi qalqalah. Setelah mengetahui sebagaimana siswa paham mengenai materi qalqalah, barulah metode 'allimna di terapkan mulai siklus I sampai II.

3. Obseravasi yaitu mengamati atas hasil atau dampak dari tindakan yang telah dilaksanakan di kelas. Peneliti melakukan pengamatan langsung terhadap pelaksanaan tindakan yang dilakukan dalam PTK.

4. Refleksi yaitu peneliti mengkaji, melihat dan mempertimbangkan atas hasil atau dampak yang muncul dari tindakan dengan berbagai kriteria. Melalui refleksi, peneliti menetapkan apa yang telah dicapai, apa yang belum dicapai serta apa yang perlu diperbaiki lagi dalam pembelajaran berikutnya.

\section{HASIL DAN PEMBAHASAN}

Data hasil penelitian yang akan dipaparkan adalah data hasil reka,man tentang beberapa hal yang menyangkut pelaksanaan selama tindakan penelitian berlangsung. Pada tahap dipaparkan hasil penelitian tentang Penerapan Metode 'Allimna Untuk Meningkatkan Kualitas Membaca AlQur'an Pada Pembelajaran Tajwid Materi Qalqalah Santri TPQ Misbahul Huda Gayasan-A Jenggawah Jember. Siklus I terdiri dari dua pertemuan dan untuk siklus II terdiri dari satu pertemuan. Dalam satu siklus terdiri atas tahap perencanaan, pelaksanaan, dan refleksi. Penelitian dapat dideskripsikan secara rinci, adapun penelitiannya sebagai berikut:

\section{Paparan Data Pra Tindakan}

Sebelum penelitian dilakukan, peneliti mengadakan pertemuan dengan ustadzah TPQ Misbahul Huda Gayasan-A Jenggawah Jember. Pada pertemuan tersebut peneliti meminta izin untuk melakukan penelitian di TPQ Misbahul Huda Gayasan-A Jenggawah Jember. Setelah peneliti mendapatkan izin untuk penelitian di TPQ Misbahul Huda Gayasan-A Jenggawah Jember, peneliti mewawancarai ustadzah Aida perihal kondisi santri TPQ Misbahul Huda 
Gayasan-A Jenggawah Jember kelas Jilid 3. Dari hasil pertanyaan yang diajukan kepada ustadzah, peneliti menyimpulkan bahwa peneliti perlu melakukan pre test terlebih dahulu.

Sesuai kesepatan dengan Ustadzah Aida, peneliti memasuki kelas jilid 3 pada hari Senin, 14 Desember 2020. Peneliti mengamati kondisi santri jilid 3 yang dijadikan subyek penelitian. Dan pada hari itu juga sesuai rencana, peneliti sekalian mengadakan tes awal (pre test). Test awal tersebut diikuti oleh semua santri jilid 3 yaitu sebanyak 10 santri. Pada test awal ini peneliti8 memberikan 10 soal pilihan ganda.

Pre test berlangsung dengan tertib dan lancar selama 30 menit. Adapun penjabaran proses pre test dapat di jelaskan sebagai berikut:

a. Kegiatan awal peneliti memberikan salam, peneliti mengajak peserta didik membaca doa sebelum belajar, lalu peneliti mengabsen santri satu persatu.

b. Kegiatan inti peneliti membagikan soal pre test (tes awal) kepada santri untuk mengetahui sejauh mana tingkat pengetahuan santri.

c. Kegiatan akhir peneliti memberikan motivasi yang bermanfaat sebelum meninggalkan kelas, dan peneliti juga menyampaikan bahwa pelajaran pada pertemuan selanjutnya akan disampaikan materi Qalqalah. Lalu peneliti mengakhiri pembelajaran dengan mengajak santri membaca doa selesai belajar bersama-sama dan mengucapkan salam.

Selanjutnya peneliti melakukan pengoreksian terhadap lembar jawaban santri untuk mengetahui nilai pre test. Adapaun hasil pre test dapat dilihat pada tabel berikut:

Tabel 1. Hasil Pre Test

\begin{tabular}{lllll}
\hline No & Nama & Jenis Kelamin & Nilai & Keterangan \\
\hline 1 & Nilna & P & 80 & Tuntas \\
\hline 2 & Rafika & P & 70 & Tidak tuntas \\
\hline 3 & Sofia & P & 80 & Tuntas \\
\hline 4 & Rendy & L & 40 & Tidak tuntas \\
\hline 5 & Bayu & L & 60 & Tidak tuntas \\
\hline 6 & Rifki & L & 50 & Tidak tuntas \\
\hline 7 & Fadil & L & 80 & Tuntas \\
\hline 8 & Beril & P & 90 & Tuntas \\
\hline 9 & Afni & P & 20 & Tidak tuntas \\
\hline 10 & Aini & P & 60 & Tidak tuntas \\
\hline & & & & \\
\hline
\end{tabular}

Berdasarkan tabel 1, dapat diketahui dari 10 santri yang mengikuti pre test, diketahui hanya 4 santri yang tuntas, dan 6 santri tidak mencapai ketuntasan dalam belajar.

Tabel 2. Analisis Hasil Pre Test

\begin{tabular}{lll}
\hline No & Uraian & Hasil Pre Test \\
\hline 1 & Jumlah santri seluruhnya & 10 \\
\hline 2 & Jumlah santri yang telah tuntas & 4 \\
\hline 3 & Jumlah santri yang tidak tuntas & 6 \\
\hline 4 & Jumlah skor yang diperoleh & 630 \\
\hline
\end{tabular}




\begin{tabular}{lll}
\hline 5 & Nilai rata-rata kelas & 63 \\
\hline 6 & Presentase ketuntasan & $40 \%$ \\
\hline 7 & Presentase ketidak tuntasan & $60 \%$ \\
\hline
\end{tabular}

Berdasarkan tabel 2 dapat diketahui bahwa nilai rata-rata santri jilid 3 TPQ Misbahul Huda Gayasan-A Jenggawah Jember pada tes awal ini adalah 63 dengtan presentase ketuntasan adalah $40 \%$. Ini berarti hasil yang diperoleh tidak sesuai dengan yang diharapakan oleh peneliti yakni $75 \%$. Hasil tes ini nantinya akan peneliti gunakan sebagai acuan peningkatan hasil belajar yang akan dicapai oleh santri. Berdasarkan hal tersebut peneliti akan mengadakan penelitian tindakan kelas guna meningktakan kualitas membaca al-Qur'an pada pembelajaran tajwid materi qalqalah santri, sehingga ketuntasan kelas dapat tercapai setidak tidaknya $75 \%$ dari jumlah keseluruhan santri dengan nilai $\geq 75$.

\section{Paparan Data Pelaksanaan Tindakan}

a. Paparan Data Pelaksanaan Tindakan

Siklus I dilaksanakan sebanayak dua kali pertemuan dengan rencana kegiatan pembelajaran yaitu pertemuan pertama dilaksanakan pada hari Selasa tanggal 15 Desember 2020 dengan alokasi waktu 2x30 menit. Melaksanakan kegiatan pembelajaran dengan pokok bahasan yaitu hukum bacaan Qalqalah. Sedangkan peretemuan kedua dilaksanakan pada hari Rabu tanggal 16 Desember 2020 dengan alokasi waktu 2x30 menit. Pertemuan kedua digunakan untuk melaksakana tes akhir siklus I sebagai dari materi yang diberikan pada siklus I sebagai respon dari materi yang diberikan. Tahap tindakan yang dilaksanakan pada siklus I dipaparkan penliti sebagai berikut:

1) Tahap Perencanaan Tindakan

Tahap yang dilakukan peneliti pada siklus I menyusun dan mempersiapkan instrumeninstrumen penelitian terkait materi hukum bacaan qalqalah.

2) Tahap Pelaksanaan Tindakan

Pelaksanaan Tindakan Siklus I dibagi dalam dua kali pertemuan yaitu:

\section{Pertemuan I}

Pertemuan I dilaksanakan pada hari Selasa tanggal 15 Desember 2020 peneliti memulai pembelajaran pada pukul 16.00-17.00 WIB dengan alokasi 2x30 menit.Pada pertemuan ini peneliti menyamnpaikan materi hukum bacaan qalqalah. Kegiatan awal, peneliti memulai kegiatan awal pembelajaran dengan mengucapkan salam dan doa bersama. Kegiatan inti, peneliti menyampaikan materi hukum bacaan qalqalah di depan kelas. Kegiatan akhir, pada tahap ini peneliti memberikan pertanyaan lisan secara acak untuk mengtetahui pemahaman santri dan penliti memberi informasi kepada santri bahwa pertemuan berikutnya akan diadakan post test siklus I. Oleh karena itu peneliti 
mengingatakan santri agar mempelajari materi yang telah disampaikan. Dan setelah itu mengakhiri pembelajaran dengan membaca doa bersama.

\section{Pertemuan II}

Pertemuan II dilakasanakan pada hari Rabu tanggal 16 Desember 2020 pada pukul 16.00-17.00 WIB. Peneliti mengawali kegiatan dengan mengucapakan salam dan berdoa bersama. Kemudian peneliti mendektekan soal sebagai evaluasi bagi santri untuk pertemuan siklus I. Soal yang dektekan oleh peneliti terdiri dari 5 soal uraian dan 1 soal lisan. Sebelum mengerjakan soal, peneliti meminta peserta didik untuk memperhatikan pnejelasan peneliti terlebih dahulu agar ketika mengerjakan santri bisa kondusif. Peneliti juga meminta agar semua buku dimasukkan kedalam tas. Setelah waktu post test siklus I selesai, santri diminta untuk mengumpulkan jawaban.

Analisis hasil belajar santri pada soal post test siklus I dengan jumlah 5 soal uraian dan 1 soal lisan.

Tabel 3. Hasil Post Test Siklus I

\begin{tabular}{lllll}
\hline No & Nama & $\begin{array}{l}\text { Jenis } \\
\text { Kelamin }\end{array}$ & Nilai & Keterangan \\
\hline 1 & Nilna & P & 90 & Tuntas \\
\hline 2 & Rafika & P & 78 & Tuntas \\
\hline 3 & Sofia & P & 80 & Tuntas \\
\hline 4 & Rendy & L & 70 & Tidak tuntas \\
\hline 5 & Bayu & L & 80 & Tuntas \\
\hline 6 & Rifki & L & 50 & Tidak tuntas \\
\hline 7 & Fadil & L & 84 & Tuntas \\
\hline 8 & Beril & P & 100 & Tuntas \\
\hline 9 & Afni & P & 32 & Tidak tuntas \\
\hline 10 & Aini & P & 70 & Tidak tuntas \\
\hline
\end{tabular}

Berdasarkan tabel 3, dapat diketahui dari 10 santri yang mengikuti pre test, diketahui hanya 6 santri yang tuntas, dan 4 santri tidak mencapai ketuntasan dalam belajar.

Tabel 4. Analisis Hasil Post Test Siklus I

\begin{tabular}{lll}
\hline No & Uraian & Hasil Post Test Siklus I \\
\hline 1 & Jumlah santri seluruhnya & 10 \\
\hline 2 & Jumlah santri yang telah tuntas & 6 \\
\hline 3 & Jumlah santri yang tidak tuntas & 4 \\
\hline 4 & Jumlah skor yang diperoleh & 734 \\
\hline 5 & Nilai rata-rata kelas & 73,4 \\
\hline 6 & Presentase ketuntasan & $60 \%$ \\
\hline 7 & Presentase ketidak tuntasan & $40 \%$ \\
\hline
\end{tabular}


Berdasarkan tabel 4, dapat peneliti ketahui jumlah persentase santri yang tuntas adalah 60\% dengan jumlah 6 santi, dan jumlah santri yangt belum tuntas yakni $40 \%$ dengan jumlah 4 santri.

3) Tahap Observasi

Tahap observasi dilakukan bersamaan dengan pelaksanaan tindakan. Pada tahap ini peneliti mengamati kegiatan dan keaktifan santri dalam emenrima materi yang diajarkan. Berdasartkan hasil observasi, para santri sudah bisa dikatan aktif dalam belajar hanya saja ada beberapa santri yang perlu diberti penekanan agar lebih aktif lagi dalam proses pembelajaran.

4) Tahap Refleksi

Dalam pelaksanaan penggunaan metode 'Allimna ini pertama kami sangat gugup, karena kami takut ada kesalahan dalam penyampaiannya. Disini sebelumnya kami juga melihat kondisi kelas bagaimana dan berusaha menyesuaikan diri di kelas yang kami ajar. Kami bisa melihat bahwa penggunaan metode 'Allimna di TPQ ini sangat membantu santri dalam membaca Al-Qur'an terlebih dalam penerapan tajwid hukum bacaan qalqalah, karena yang kami lihat santri sangat bersemangat dalam membacanya dan santri juga mudah untuk memahami dalam penyampian materi yang diajarakan. Sehingga hal itu juga mempercepat santri dalam memperlancar membaca Al-Qur'an beserta tajwidnya. Pada tahap ini peneliti berencana untuk berupaya memberikan penekanan materi yang belum dipahami santri, peneliti berupaya mengkondisikan kelas dengan baik, peneliti berupaya memaksimalkan performance dikelas dan memenuhi aktivitas yang belum terpenuhi.

b. Paparan Data Siklus II

Siklus II dilaksanakan untuk memperbaiki tindakan dari siklus I. Pelaksanaan siklus II terbagi menjadi tiga tahapan, yaitu tahap perencanaan, pelaksanaan, dan refleksi.

1) Tahap Perencanaan

Tahap perencanaan tindakan dilakukan oleh peneliti dengan membuat terlebih dahulu beberapa hal sebagai berikut:

a) Membuat RPP (Rencana Pelaksanaan Pembelajaran)

b) Menyiapkan materi tentang hukum bacaan qalqalah

c) Menyiapkan lembar test siklus II

2) Tahap Pelaksanaan Tindakan

Penelitian pada siklus II ini dilakukan hanya satu kali pertemuan kemudian dilanjutkan post test siklus II sebagai respon dari materi yang diberikan. Untuk pelaksanaannya sendiri siklus II ini dilaksanakan pada hari Kamis 17 Desember 2020 
dengan alokasi waktu $2 \times 30$ menit.Tahap awal, peneliti bertindak sebagai ustadzah. Peneliti mengkondisikan santri sebelum memulai pembelajaran, setelah santri siap untuk belajar, peneliti mengucapakan salam serta berdoa bersama. Sebelum membahas materi yang akan dijelasakan, peneliti terlebih dahulu melakukan tanya jawab kepada santri tentang hukum bacaan qalqalah yang sudah dijelaskan pada hari sebelumnya. Setelah itu ustadzah memberikan penejelasan lebih dalam lagi terkait materi hukum bacaan qalqalah. Setelah santri dirasa cukup paham dengan materi dan tidak ada pertanyaan lain, ustdazah membagikan soal pada semua santri sebagai tes akhir pada pertemuan hari itu, dan meminta santri untuk mengerjakan soal-soal tersebut dengan teliti. Pada saat tes berlangsung ustadzah berusaha memantau jalannya post test supaya post test berjalan dengan tertib dan hasil yang didapat merupakan nilai santri yang sebenarnya. Selain itu, ustadzah juga mengingatkan santri agar mengerjakan semua soal dengan lebih teliti. Soal pada post test siklus II ini berisi 10 soal pilhan ganda.

Adapun analisis hasil belajar santri post test siklus II dapat dilihat sebagai berikut:

Tabel 5. Hasil Post Test Siklus II

\begin{tabular}{lllll}
\hline No & Nama & $\begin{array}{l}\text { Jenis } \\
\text { Kelamin }\end{array}$ & Nilai & Keterangan \\
\hline 1 & Nilna & P & 100 & Tuntas \\
\hline 2 & Rafika & P & 80 & Tuntas \\
\hline 3 & Sofia & P & 100 & Tuntas \\
\hline 4 & Rendy & L & 100 & Tuntas \\
\hline 5 & Bayu & L & 90 & Tuntas \\
\hline 6 & Rifki & L & 100 & Tuntas \\
\hline 7 & Fadil & L & 80 & Tuntas \\
\hline 8 & Beril & P & 100 & Tuntas \\
\hline 9 & Afni & P & 40 & Tidak tuntas \\
\hline 10 & Aini & P & 80 & Tuntas \\
\hline
\end{tabular}

Berdasarkan tabel 5, dapat dikatakan bahwa dari 10 santri terdapat 9 santri yang tuntas dan hanya 1 santri yang belum mencapai kriteria ketuntasan minimal (KKM) yaitu $\geq 75$. Berikut perinciannya:

Tabel 6. Analisis Hasil Post Test Siklus II

\begin{tabular}{llc}
\hline No & Uraian & Hasil Post Test Siklus II \\
\hline 1 & Jumlah santri seluruhnya & 10 \\
\hline 2 & Jumlah santri yang telah tuntas & 9 \\
\hline 3 & Jumlah santri yang tidak tuntas & 1 \\
\hline 4 & Jumlah skor yang diperoleh & 870 \\
\hline 5 & Nilai rata-rata kelas & 87 \\
\hline 6 & Presentase ketuntasan & $90 \%$ \\
\hline 7 & Presentase ketidak tuntasan & $10 \%$ \\
\hline
\end{tabular}


Berdasarkan tabel 6, menunjukkan bahwa hasil post test siklus II mengalami peningkatan dari pada post test siklus I. Dapat diketahui bahwa rata-rata kelas 87 dengan jumlah ketuntasan 90\% (9 santri), dan jumlah ketidak tuntasan 10\% (1 santri).

Tabel 7. Perbandingan Hasil Pre Test, Post Test Siklus I dan Post Test Siklus II

\begin{tabular}{|c|c|c|c|c|c|}
\hline No & Nama & $\begin{array}{l}\text { Jenis } \\
\text { Kelamin }\end{array}$ & $\begin{array}{l}\text { Nilai } \\
\text { Pre } \\
\text { Test }\end{array}$ & $\begin{array}{l}\text { Nilai Post } \\
\text { Test Siklus } \\
\text { I }\end{array}$ & $\begin{array}{l}\text { Nilai Post } \\
\text { Test Siklus } \\
\text { II }\end{array}$ \\
\hline 1 & Nilna & $\mathrm{P}$ & 80 & 90 & 100 \\
\hline 2 & Rafika & $\mathrm{P}$ & 70 & 78 & 80 \\
\hline 3 & Sofia & $\mathrm{P}$ & 80 & 80 & 100 \\
\hline 4 & Rendy & $\mathrm{L}$ & 40 & 70 & 100 \\
\hline 5 & Bayu & $\mathrm{L}$ & 60 & 80 & 90 \\
\hline 6 & Rifki & $\mathrm{L}$ & 50 & 50 & 100 \\
\hline 7 & Fadil & $\mathrm{L}$ & 80 & 84 & 80 \\
\hline 8 & Beril & $\mathrm{P}$ & 90 & 90 & 100 \\
\hline 9 & Afni & $\mathrm{P}$ & 20 & 32 & 40 \\
\hline 10 & Aini & $\mathrm{P}$ & 60 & 70 & 80 \\
\hline \multicolumn{3}{|c|}{ Total Skor } & 630 & 734 & 870 \\
\hline \multicolumn{3}{|c|}{ Rata-Rata } & 63 & 73,4 & 87 \\
\hline \multicolumn{3}{|c|}{ Jumlah santri keseluruhan } & 10 & 10 & 10 \\
\hline \multicolumn{3}{|c|}{ Jumlah santri yang telah tuntas } & 4 & 6 & 9 \\
\hline \multicolumn{3}{|c|}{ Jumlah santri yang tidak tuntas } & 6 & 4 & 1 \\
\hline \multicolumn{3}{|c|}{ Jumlah santri yang tidak ikut test } & - & - & - \\
\hline \multicolumn{3}{|c|}{ Presentase ketuntasan } & $40 \%$ & $60 \%$ & $90 \%$ \\
\hline \multicolumn{3}{|c|}{ Presentase ketidak tuntasan } & $60 \%$ & $40 \%$ & $10 \%$ \\
\hline
\end{tabular}

Berdasarkan data perbandingan tabel 7 , terjadi peningkatan hasil belajar yang dialami oleh santri, peningkatan ini dilalui denga tiga tahap yaitu pertama dengan pre test hasil belajar santri kurang baik karen apresentase ketidaktuntasan santri 60\%. Kemudian peneliti melakukan perbaikan dengan melakukan post test siklus I disini terajdi peningkatan hasil belajar santri tetapi masih kurang mencapai hasil yang memuasakan yaitu dengan tingkat ketidak tuntasan menjadi $40 \%$. Peneliti masih kurang puas dengan hasil yang diperoleh pada post test siklus I sehingga peneliti melanjutkan penelitian dengan melakukan post test siklus II, pada penerapannya terjadi peningkatan yang memuaskan pada hasil belajar santri yaitu tingkat ketidak tuntasan santri $10 \%$ saja atau hanya 1 santri yang tidak tuntas.

3) Tahap Observasi

Tahap observasi dilakukan bersamaan dengan pelaksanaan tindakan. Pada tahap ini peneliti mengamati kegiatan dan keaktifan santri dalam emenrima materi yang diajarkan. Berdasarkan hasil observasi, keaktifan santri sudah meningkat dibandingkan hari sebelumnya. Dan dengan adanya peningkatan keaktifan santri, hal ini menunjukkan adanya peningkatan pemahaman santri terhadap pembelajaran tajwid materi qalqalah. 
4) Tahap Refleksi

Dalam pelaksanaan mengajar dengan menggunakan metode 'Allimna yang kami gunakan sangat membantu kami dan santri yang kami ajar, karena metode ini belajar santri lebih mudah memahami dan metode ini juga sangat menyenangkan sehingga santri lebih mudah dalam belajar al-Qur'an beserta tajwid-tajwidnya. Metode ini juga dilengkapi dengan lagu-lagu dalam penerapannya sehingga santri juga lebih cepat dalam menghafal ilmu-ilmu tajwid dan juga tidak membuat bosan para santri dalam belajar al quran. Metode ini juga sangat cocok untuk semua kalangan. Selama kami mengajar, kami melihat santri sangat bersemangat dalam mengikuti pembelajaran dengan menggunakan metode allimna ini. Dengan menggunakan metode allimna ini juga sangat membantu kami dalam mengajar, karena penyampainnya juga dapat diserap secara cepat oleh santri. Dan selama kami mengajar menggunakan metode ini, terus ada peningkatan terhadap nilai santri setiap harinya sehingga kami dapat menyimpulkan bahwa metode allimna ini sangat membantu kami dan cocok untuk diterapkan kepada santri untuk cara cepat dalam belajar al quran di TPQ.

Berdasarkan kegiatan yang dialakukan peneliti bersama pada post test siklus II ini peneliti mengadakan refleksi terhadap hasil test akhir siklus II, maka dapat diperoleh hasil sebagai berikut:

a) Penggunaan metode "Allimna dalam pembelajaran sudah sesuai dengan langkahlangkah pembelajaran.

b) Melalui metode Allimna santri lebih bersemangat belajar.

c) Kemampuan belajar santri tergolong baik berdasarkan hasil observasi.

d) Hasil belajar santri berdasarkan hassil post test siklus II menunjukkan peningkatan dibandingkan dengan hasil post test siklus I.

e) Santri tampak lebih aktif dalam pembelajaran.

f) Aktivitas peneliti sudah menunjukkna tingkat keberhasilan pada kriteriua baik. Oleh karena itu tidak perlu pengulangan siklus.

g) Aktivitas santri sudah menunjukkan tingkat keberhasilan baik. Oleh karena itu tidak diperlukan pengulangan siklus.

Penelitian ini dilakukan sebanyak dua siklus, yaitu siklus I dilakukan dua kali pertemuan yakni tanggal 15 Desember dan 16 Desember 2020, sedangkan siklius II dilaksanakan satu kali pertemuan yakni tanggal 17 Desember 2020. Sebelum melakukan tindakan, peneliti melakukan tes awal (pre test) untuk mengtahui seberapajauh pemahaman santri tentang materi hukum bacaan qalqalaah yang akan disampaikan. Dari analisis test awal (pre test) memang diperlukan tindakan untuk meningkatkan hasl belajatr santri pada materi hukum bacaan qalqalah. 
Berdasarkan hasil penelitian, terdapat satu santri yang tidak lulus diakhir siklus yaitu santri yang bernama Afni. Hal ini disebabkan beberapa hal, karena memang dalam proses belajar ada beberapa fakor yang mempengaruhi prestasi belajar individu. Faktor yang mempengaruhi keberhasilan belajar terbagi menjadi faktor intrnal dan faktor eksternal. Adapun salah satu faktor intertnalnya yaitu faktor psikologis. Faktor psikologis yang mempengaruhi keberhasilan belajar ini meliputi segala hal yang berkaitan dengan kondisi mental seseorang (Hakim, 2008: 12). Hal ini berkaitan dengan kemampuan sesorang dalam menyerap materi belajar yaitu faktor intelektual. Sebagaiman dikatakan oleh W.S. Winkel bahwa faktor intelektual meliputi taraf inteligensi, kemampuan belajar dan cara belajar (Arbangi et al., 2016: 169). Afni ini memiliki taraf inteligensi dan kemampuan belajar yang berbeda dengan santri lainnya. Bahkan dia juga memiliki gaya atau cara belajarnya sendiri. Atau bisa dikatakan bahwa afni ini memiliki taraf inteligensi yang lebih rendah dibandingkan dengan teman-teman yang lainnya. Sehingga metode 'allimna yang disampaikan oleh peneliti belum sepenuhnya terserap oleh santri ini. Hal ini perlu adanya upaya lebih dari sang peneliti untuk membuat prestasi belajar afni dapat dikatan berhasil yaitu dengan memenuhi nilai ketuntasan yang sudah ditentukan.

Selain faktor di atas, keberhasilan belajar juga ditunjang oleh beberapa faktor lain seperti kemauan, fasilitas dan metode dalam pembelajaran. Karena dengan taraf inteligensi yang tinggi tidak menjadi sesorang memliki prestasi belajar yang tinggi jika tidak didukung oleh beberapa faktor tersebut. Jika melihat hasil penelitian, banyak santri yang tuntas daripada santri yang tidak tuntas. Hal ini dikarenakan metode yang digunakan dalam proses pembelajaran sesuai dengan kebutuhan dan kondisi santri di TPQ tersebut.Dalam proses pembelajaran, metode diibarakan sebagai pendorong atau kekuatan untuk meningkatkan dan mengangkut muatan materi pembelajaran sampai ke tujuan demi kepentingan peserta didik (Prayitno, 2009: 55). Untuk pemilihan metode pembalajaran harus disesuaikan dengan kebutuhan peserta didiknya. Adapun metode yang digunakan pada penlitian kali ini adalah Metode 'Allimna. Metode ini sesuai dengan kebutuhan dan kodisi santri pada TPQ tersebut. Kebanyakan santri disini lebih suka dengan proses pembelajaran yang menyenagkan seperti nyanyi-nyai yang diterapkan metode 'Allimna dengan menggunakan lagu-lagu dalam proses belajar. Oleh karena itu, tidak heeran jika banyak santri yang mengalami kenaikan nilai hasil belajar setelah menggunakan metode ini dalam proses belajar membaca Al-Qur'an materi qalqalah.

Penelitian ini dilakukan sebagai upaya untuk meningkatkan kualitas membaca al-qur'an pada pembelajaran tajwid materi qalqalah dengan menggunaka metode Allimna. Dengan menggunakan metode Allimna ini pembelajaran tajwid menjadi lebih menyenangkan dan lebih mudah dipahami dengan penggunaan lagu dalam proses pembelajaran. Dengan menggunakan metode Allimna, santri dapat meraih keberhasilan dalam belajar hukum bacaan qalqalah, selain itu santri merasa senang saat proses pembelajaran berlangsung. Metode 'Allimna memungkinkan 
santri untuk belajar dengan mudah dan bersemangat dalam suasana belajar yang menyenangkan. Lagu yang ada pada metode "Allimna ini memudahkan santri dalam menyerap materi tentang hukum bacaan qalqalah yang diajarkan oleh peneliti. Penerapan metode 'Allimna ini mampu meningkatakan hasil bealajar santri pada materi hukum bacaan qalqalah.

\section{KESIMPULAN DAN SARAN}

Berdasarkan hasil penelitian dapat disimpulkan bahwa metode 'allimna sangat efektif dalam meningkatkan kemampuan membaca al-Qur'an pada pembelajaran tajwid materi qalqalah santri TPQ Misbahul Huda Gayasan-A Jenggawah Jember. Hal ini dibuktikan dengan hasil post test siklus II yang mengalami peningkatan lebih besar dari pada post test siklus I.

Para pendidik TPQ direkomendasikan memakai metode 'allimna sebagai metode pembelajarannya agar meningkatkan kemampuan membaca al-Qur'an, bukan hanya materi qalqalah tetapi juga materi-materi lainnya. Selain itu, penelitian tema yang sama dapat dilakukan pada satuan pendidikan lain, baik formal maupun nonformal.

\section{DAFTAR PUSTAKA}

Aidah, Siti Nur. 2020. Panduan Lengkap belajar Ilmu Tajwid. Yogayakarta: Penerbit KBM Indonesia.

Arbangi, Dakir dan Umiarso. 2016. Manajemen Mutu Pendidikan. Jakarta: Kencana.

Bahtiar, Achmad. 2018. Implementasi Model Pembelajaran Kooperatif Tipe Student Team Achievement Division (STAD) dalam Meningkatkan Prestasi Belajar Siswa Pada Mata Pelajaran Pendidikan Agama Islam Materi Hukum Qalqalah, Ra dan Lam di Kelas IX-4 SMP Negeri 1 Patumbak. Intiqad: Jurnal Agama dan Pendidikan Islam.

Fahrisi, Ahmad. 2020. Kecerdasan Spritual dan pendidikan Islam. Jakarta: Guepedia.

Hakim, Thursan. 2008. Belajar Secara Efektif. Jakarta: Puspa Swara.

https://allimna.wordpress.com

Marzuki, dkk. 2020. Dasar-dasar Ilmu Tajwid. Yogyakarta: DIVA Press.

Pandiangan, Anjani Putri Belawati. 2019. Penelitian Tindakan Kelas Sebagai Upaya Peningkatan Kualitas Pembelajaran, Profesionalisme Guru dan Kompetensi Belajar Siswa. Yogyakarta:Deepublish.

Prayitno. 2009. Dasar Teori dan Praksis Pendidikan. Jakarta: Grasindo.

Sayuti. Ilmu Tajwid Lengkap. Sangkala.

Sembodo, Bagus Priyo. 2019. Upaya Meningkatkan Prestasi Belajar PAI Materi Pokok Hukum Bacaan Qalqalah dan Ra' Melalui Metode drill Pada Siswa Kelas VII SMPMA'ARIF 5 Ngrupit Ponorogo 2018-2019. Ponorogo: IAIN Ponorogo. 
Syarbani, Amirullah. 2012. Kedahsyatan membaca Al Quran. Yogyakarta: Penerbit Ruang Kata Imprint Kawan Pustaka. 